PSICOLOGIA, SAÚDE \& DOENÇAS, 2017, 18(3), 846-858

ISSN - 2182-8407

Sociedade Portuguesa de Psicologia da Saúde - SPPS - www.sp-ps.pt

DOI: http://dx.doi.org/10.15309/17psd180317

\title{
AGENCY AND EXPRESSIVENESS IN MIDDLE AND OLDER AGED PORTUGUESE MEN AND WOMEN
}

Pedro Alexandre Costa (pcosta@ispa.pt) ${ }^{1 \square}$, Paula Mangia (pmangia@ispa.pt) ${ }^{1}$, Carolina Correia Tomás (cneves@ispa.pt) ${ }^{1}$, Filipa Pimenta (filipa_pimenta@ispa.pt) ${ }^{1}$, João Maroco (jpmaroco@ispa.pt) ${ }^{1}$, \& Isabel Leal'(ileal@ispa.pt)

\footnotetext{
${ }^{1}$ William James Center for Research, ISPA - Instituto Universitário, Rua Jardim do Tabaco, 34, 1149-041 Lisboa,
} Portugal

\section{AGENCY AND EXPRESSIVENESS IN MIDDLE AND OLDER AGED PORTUGUESE MEN AND WOMEN}

\begin{abstract}
Bem's model of gender roles (Bem, 1974, 1981a) proposed that psychological masculinity and femininity are two separate and orthogonal dimensions, and further supported the advantages of a shared masculine and feminine personality in comparison to a gendered personality. The aim of this study was to evaluate the psychometric properties of the Bem Sex-Role Inventory (BSRI) in Portugal, specific to two essential dimensions of gender roles - Agency/Instrumentality and Expressiveness. This study was part of a larger study about perceived health in both middle and older aged men and women. The sample consisted of 630 Portuguese adults (53.3\% women), aged between 40 and $86(M=51.52, S D=8.4)$. To assess construct validity, an Exploratory Factor Analysis was performed, confirming the two-dimensional model of Agency/Instrumentality (9 items) and Expressiveness (9 items), and with a high internal consistency. Afterwards, Confirmatory Factor Analyses were performed, and confirmed the two-dimensional first-order model with 18 items among men and women separately, and in the total sample. Lastly, a Multi-group Confirmatory Factor Analysis was performed, and the invariance between gender groups was confirmed. The current study provided evidence of good psychometric and factorial validity of the 18 -item version of BSRI for a middle and older aged Portuguese sample.
\end{abstract}

Keywords: gender roles, gender, validation, BSRI

\section{AGÊNCIA E EXPRESSIVIDADE EM HOMENS E MULHERES PORTUGUESES NA MEIA-IDADE E AVAÇADA}

RESUMO: O modelo de Bem de papeis de género (Bem, 1974, 1981a) propõe que a masculinidade e a feminilidade são duas dimensões separadas e ortogonais, defendendo as vantagens de uma personalidade com características masculinas e femininas em detrimento de uma personalidade tipificada. Este estudo teve como objetivo avaliar as qualidades psicométricas do Bem Sex-Role Inventory (BSRI) em Portugal, especificamente duas dimensões essenciais de papeis de género Agência/Instrumentalidade e Expressividade. Este estudo faz parte de um estudo alargado sobre saúde percebida em homens e mulheres de meia idade e de idade

${ }^{\square}$ Rua Jardim do Tabaco, 34, 1149-041 Lisboa, Portugal. Telf.: +351 218811700. e-mail: pcosta@ispa.pt 


\section{P.A. Costa, P. Mangia, C.C.Tomás, F. Pimenta, J.Maroco, \& I. Leal}

avançada. A amostra consistiu em 630 adultos (53.3\% mulheres), com idades compreendidas entre os 40 e os 80 anos $(M=51.52 ; D P=8.4)$. A validade de constructo foi avaliada através de Análise Fatorial Exploratória, que confirmou o modelo bidimensional de Agência/Instrumentalidade (9 itens) e Expressividade (9 itens), apresentando uma elevada consistência interna. Posteriormente, foi realizada uma Análise Fatorial Confirmatória, que confirmou o modelo de primeira ordem bidimensional com 18 itens em homens e mulheres separadamente, e na amostra total. Por fim, foi feita uma Análise Fatorial Confirmatória Multigrupos que confirmou a invariância entre géneros. O presente estudo fornece evidências de boa validade psicométrica e fatorial da versão de 18 itens do BSRI numa amostra de Portugueses de meia-idade e idade avançada.

Palavras-chave: papeis de género, género, validação, BSRI

Recebido em 06 de Dezembro de 2016/ Aceite em 16 de Novembro de 2017

Gender is one of the first social categories that is learned and evidenced since early childhood (Steffens \& Viladot, 2015), and gender-related stereotypes are internalized and become part of the construction of self-concepts in adulthood (Kachel, Steffens \& Niedlich, 2016; Nosek, Banaji \& Greenwald, 2002; Steffens, Jelenec \& Noack, 2010). Gender roles may be defined as what is socially expected and considered as appropriate characteristics and behavior for each gender, and reflect status and power differences according to the position that men and women have in the gender hierarchy (Eagly, Wood \& Diekman, 2000).

Understanding gender role's perceptions and the corresponding attitudes and behaviors has been the aim of numerous research in the field of psychology (Holt \& Ellis, 1998). Several psychological theories seek to explain the development of gender roles, such as Psychoanalysis, Social Learning Theory (Bussey \& Bandura, 1984) and, in Socio-cognitive Theory, the Gender Schema Theory (Bem, 1981a). The latter two theories have produced the majority of scientific knowledge (Maccoby, 2000), and they both sustain the perspective of gender and gender roles as results of social constructions (Smiler \& Epstein, 2010).

Traditional notions of gender perceive masculinity and femininity as edges of the same single bipolar dimension in which there is the assumption of different social stereotypes and roles between them. However, the traditional notions of gender, as well as scientific research, had their turning point in the 1970s, when a significant change in gender roles occurred in North America, with a shift in the women's role at the workforce and educational achievement. For instance, the labor force participation rate of married women with children rose about $40 \%$ in 1970 s, and further increased more than 70\% over the following 20 years (Auster \& Ohm, 2000). Consequently, men's perceptions of gender roles, which used to be more traditional than women's, also became more liberal (Gibbons, Hamby \& Dennis, 1997; Jackson, Hodge, \& Ingram, 1994; Konrad \& Harris, 2002; Twenge, 1997). A literature review highlighted a number of measures that conceptualized masculinity and femininity as a single bipolar dimension, on which an individual can either score high or low (Auster \& Ohm, 2000). By way of contrast, Bem's model of gender roles (Bem, 1974) had one of the most comprehensive and innovative views on gender and gender roles, being later framed as the Gender Schema Theory (Bem, 1981a; Hoffman \& Borders, 2001). The Gender Schema Theory proposed that psychological masculinity and femininity are two separate and orthogonal dimensions, and further supported the advantages of having a shared masculine and feminine personality, which Sandra Bem designated as psychological androgyny (Bem, 1981a; Cheng, 2005). 


\section{AGENCY AND EXPRESSIVENESS IN MIDDLE AND OLDER AGE}

Rooted in the Gender Schema Theory, Bem created a psychological measure to assess gender role perceptions - the Bem Sex-Role Inventory (BSRI; Bem, 1974). The BSRI helped popularize the concept of psychological androgyny, i.e., the notion that an individual may possess both masculine and feminine characteristics (Cheng, 2005; Smiler \& Epstein, 2010), allowing the categorization of respondents into four groups: androgynous (high masculine/high feminine), masculine (high masculine/low feminine), feminine (low masculine/high feminine), and undifferentiated (low masculine/low feminine). To develop the BSRI, Bem (1974) was influenced by Parsons and Bales' (1955) description of femininity as expressive (e.g. "compassionate", "sympathetic") and masculinity as instrumental (e.g. "takes the lead", "competitive"; Carver, Vafaei, Guerra, Freire, \& Phillips, 2013; Smiler \& Epstein, 2010), and developed a list of approximately 400 personality traits which were presented to Stanford University undergraduate students and asked to identify how desirable those features were for a man or woman in American society (Auster \& Ohm, 2000). This procedure allowed the development of the femininity and masculinity scales, comprised by 20 items, each composed by adjectives that both female and male participants considered to be more desirable in women and men, respectively, and 20 more genderneutral items (Bem, 1974, 1981a).

Recent studies increasingly point out that there may be little differences between genders in selfdescriptions concerning general gender stereotypical traits (Sczesny, Bosak, Neff \& Schyns, 2004), which may be explained by societal changes in gender roles over time (Diekman \& Eagly, 2000; Smiler \& Gelman, 2008; Smiler, Kay, \& Harris, 2008; Twenge, 1997; Wilde \& Diekman, 2005). However, equality in gender perceptions has not been achieved, and gender differences in selfdescriptions do continue to exist (Athenstaedt, 2003; Kachel, Steffens, \& Niedlich, 2016; Konrad \& Harris, 2002; Lueptow, Garovich-Szabo, \& Lueptow, 2001). Further, given that the concept of gender roles has a dynamic feature due to its vulnerability to societal changes and cultural influences (Konrad \& Harris, 2002; Twenge, 1997), regular revisions become necessary, as well as a continued process of examination of the measures' psychometric properties.

In Portugal, research in gender roles is still scarce, and despite the fact that BSRI is one of the most widely regarded measures to assess gender roles, no study has been conducted with the purpose of adapting and examining the BSRI's reliability and validity. In order to fill this gap in the literature, the present study aims to adapt, evaluate the psychometric properties and perform a factorial validation of the Bem Sex-Role Inventory in a middle and older aged Portuguese sample, focusing on the gender dimensions Agency/Instrumentality and Expressiveness/Communication.

\section{METHOD}

This study was part of a larger study about perceived health in middle and older age men and women, for which an intentional non-probabilistic sampling method was used.

\section{Participants}

The sample consisted of 630 Portuguese adults (53.3\% women and $46.7 \%$ men) aged between 40 and 86 years $(M=51.52, S D=8.40)$; women $(M=50.78, S D=8.02)$ were significantly younger than men $(M=52.36, S D=8.75), t(628)=2.361, p=.019$. Most participants were either married or in a civil partnership (66.3\%), had a university degree (49.5\%), and had an income between 7,001€ and $20,000 €$ per year (31.9\%). The inclusion criteria used was age equal or above 40 years old and sufficient literacy to understand and fill in the questionnaire. Table 1 summarizes the characteristics of the participants for the total sample and separately by gender. 
Table 1.

Sociodemographic characteristics for the total sample and separately by gender

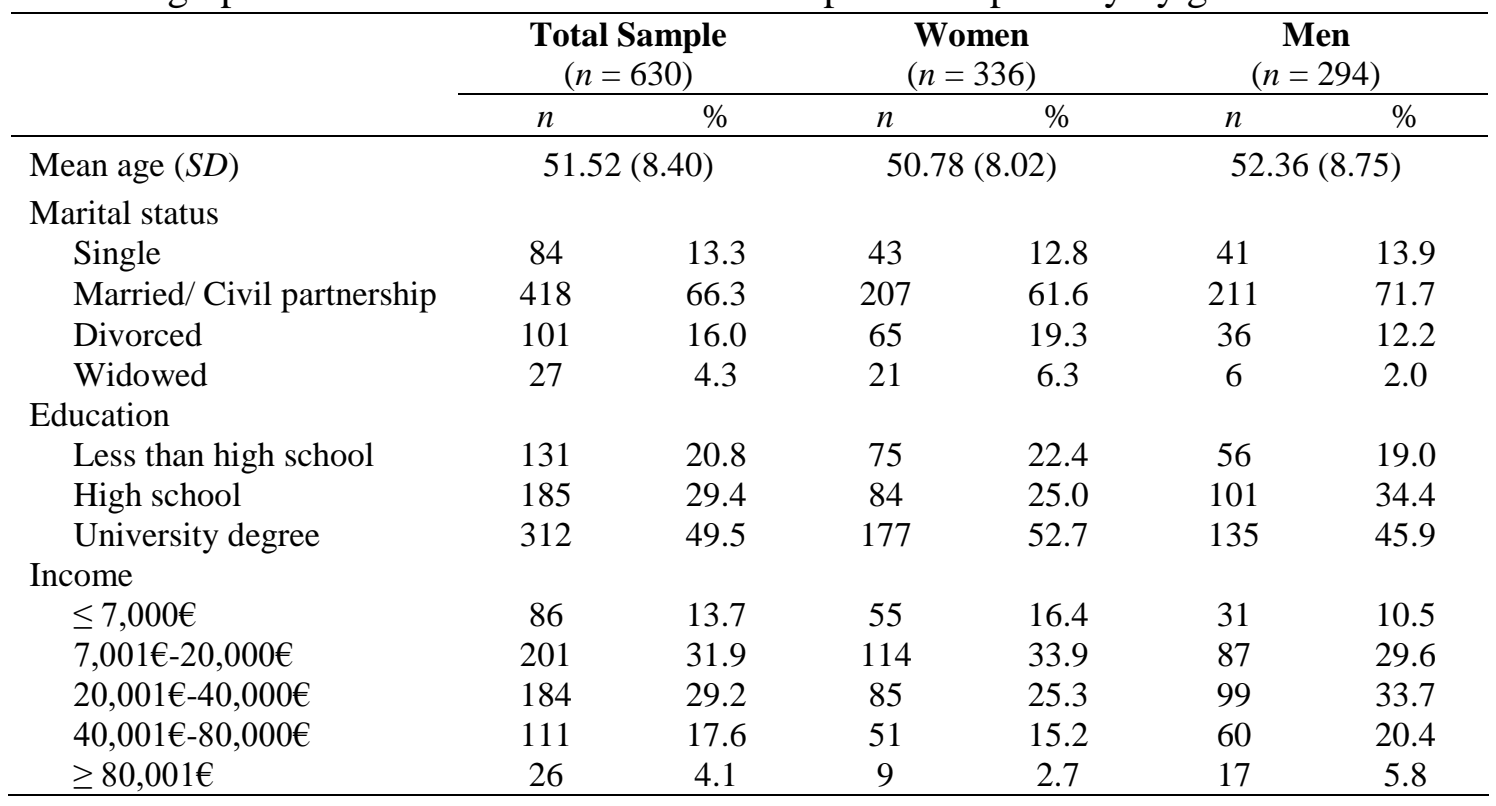

\section{Materials}

The original Bem Sex-Role Inventory (BSRI; Bem, 1974, 1981a) is composed by 60 descriptive adjectives, of which 20 measure masculinity, 20 femininity, and the remaining 20 are genderneutral fillers. Individuals are asked to rate on a 7-point Likert scale (from 1- "Never or almost never true" to 7- "Always to almost always true") to what degree each adjective describes them. Further developments by Bem (1981b) reduced the scale to half the number of items in order to improve its psychometric properties, and resulted in a 30-item instrument, with 10 items for each of the three dimensions.

BSRI has undergone many adaptations and different versions are now available (Carver, Vafaei, Guerra, Freire, \& Phillips, 2013; Colley, Mulhern, Maltby, \& Wood, 2009; Vafaei et al., 2014). For this study, we were interested in a shorter version that included only the dimensions of Agency/Instrumentality and Expressiveness, the two most common gender-role stereotypes.

The BSRI was adapted to Portuguese according to international guidelines for transcultural adaptation of measures of psychological constructs (Beaton, Bombardier, Guillemin, \& Ferraz, 2000; Guillemin, Bombardier, \& Beaton, 1993). Three bilingual researchers translated the BSRI items from English to Portuguese. Subsequently, the three translations were compared in order to achieve one parsimonious translation. The final translation was then sent to a bilingual translator to perform a retro-translation from Portuguese to English. Lastly, the final translation in Portuguese (i.e., the English retroversion) and the original inventory in English were compared. The final translation underwent an evaluation of its face validity through a focus group composed of six investigators to ensure that the adjectives were easily comprehensible and contextually relevant in Portugal.

The final version of BSRI used in the present study is composed by 20 items distributed in two dimensions: Agency/Instrumentality (10 items; e.g., "Act as leader") and Expressiveness (10 items; e.g., "Gentle"). Some items did not correspond to those used in other studies that used a similar version of the BSRI (e.g., Colley, Mulhern, Maltby, \& Wood, 2009) because the panel of experts found that some items did not resonate in the Portuguese context. Since this sample entails older 


\section{AGENCY AND EXPRESSIVENESS IN MIDDLE AND OLDER AGE}

adults we decided to also change the Likert scale to a 5-point Likert scale (from 1- "Never" to 5"Always").

\section{Procedure}

Participants were invited to answer the questionnaire in one of two ways: (1) online format, where participants were invited to fill in the questionnaire by email or through a Facebook page developed specifically for this purpose, (2) pencil-paper format, where researchers would approach in person various community settings, such as Senior Universities, and Retirement Homes, explaining the study to potential participants. In the context of the informed consent delivery, participants were assured their data would remain confidential and that they could cease their collaboration anytime without any consequences. The questionnaire took approximately 15 to 20 minutes to complete.

\section{Data analysis}

Sensitivity was measured through the analysis of the minimum and maximum scores, and of the skewness and kurtosis values, which should be below $|3|$ and $|7|$, respectively. Reliability was assessed through Cronbach's $\alpha$ and Composite Reliability values, which should be above .70 .

To evaluate construct validity, an Exploratory Factor Analysis (EFA), a Confirmatory Factor Analysis (CFA), a Multi-group Confirmatory Factor Analysis (MG-CFA) were performed, and convergent and discriminant validities were also examined. The EFA was used to explore the factor structure of the inventory through principal components analysis with Varimax rotation. Afterwards, a CFA was performed to confirm the factor structure obtained through EFA. The following goodness of fit indexes were used to assess the model fit: $\chi^{2}$ (Chi-Square), CFI (Comparative Fit Index), GFI (Goodness of Fit Index) and RMSEA (Root Mean Square Error of Approximation). Model fit is considered good when the values of CFI and GFI are above 90 and RMSEA are below .05. The MG-CFA was further performed to examine model invariance between genders through the analysis of the Chi-square Difference Statistic. Lastly, convergent and discriminant validities were assessed. To assess convergent validity, the Average Variance Extracted (AVE) was examined, and values should be above .50. To assess discriminant validity, the AVE for each factor was compared with the squared correlation between the factors, so that AVE values should be higher than the squared correlation between factors.

SPSS (v. 24.0) was used to calculate descriptive statistics, to evaluate sensitivity, and to perform the EFA. AMOS (v. 22.0) was used to perform CFA and MG-CFA, and to calculate CR, AVE and squared correlation scores.

\section{RESULTS}

\section{Sensitivity}

All items were answered using the entire scaling range, i.e., the minimum and maximum value of every item were 1 and 5 points respectively. Table 2 presents the means, standard deviations, kurtosis and skewness values per item for the total sample and considering each gender separately. Skewness and kurtosis scores provided evidence of a normal distribution. 
Table 2.

Descriptive statistics

\begin{tabular}{|c|c|c|c|c|c|c|c|c|c|c|c|c|c|}
\hline \multirow[t]{2}{*}{ \# } & \multirow[t]{2}{*}{ Item } & \multicolumn{4}{|c|}{$\begin{array}{c}\text { Total sample } \\
(n=630)\end{array}$} & \multicolumn{4}{|c|}{$\begin{array}{c}\text { Women } \\
(n=336) \\
\end{array}$} & \multicolumn{4}{|c|}{$\begin{array}{c}\text { Men } \\
(n=294) \\
\end{array}$} \\
\hline & & $M$ & $S D$ & $S k$ & $K u$ & $M$ & $S D$ & $S k$ & $K u$ & $M$ & $S D$ & $S k$ & $K u$ \\
\hline 1 & $\begin{array}{l}\text { Charitable } \\
\text { Caridosa(o) }\end{array}$ & 3.76 & .75 & -.45 & .57 & 3.82 & .73 & -.56 & .76 & 3.68 & .77 & -.33 & .26 \\
\hline 2 & $\begin{array}{l}\text { Tender } \\
\text { Sensível } \\
\text { Willing to take a stand }\end{array}$ & 4.16 & .73 & -.80 & 1.08 & 4.26 & .69 & -.85 & 1.33 & 4.05 & .77 & -.67 & .39 \\
\hline 3 & $\begin{array}{l}\text { Disposta(o) a tomar } \\
\text { uma posição } \\
\text { Sensitive to the needs } \\
\text { of others }\end{array}$ & 3.89 & .79 & -.44 & .07 & 3.83 & .81 & -.48 & .30 & 3.96 & .76 & -.39 & -.10 \\
\hline 4 & $\begin{array}{l}\text { Sensível às } \\
\text { necessidades dos } \\
\text { outros }\end{array}$ & 4.14 & .72 & -.64 & .75 & 4.21 & .69 & -.60 & .63 & 4.06 & .74 & -.64 & .83 \\
\hline 5 & $\begin{array}{l}\text { Soft spoken } \\
\text { De brandos modos }\end{array}$ & 3.68 & .88 & -.59 & .33 & 3.65 & .92 & -.54 & .21 & 3.72 & .83 & -.60 & .32 \\
\hline 6 & $\begin{array}{l}\text { Sympathetic } \\
\text { Empática }(o)\end{array}$ & 3.67 & .93 & -.76 & .59 & 3.69 & .94 & -.67 & .50 & 3.64 & .91 & -.84 & .68 \\
\hline 7 & $\begin{array}{l}\text { Willing to take risks } \\
\text { Disposta(o) a correr } \\
\text { riscos }\end{array}$ & 3.27 & 1.00 & -.13 & -.42 & 3.19 & 1.02 & -.20 & -.30 & 3.37 & .97 & -.05 & -.50 \\
\hline 8 & $\begin{array}{l}\text { Compassionate } \\
\text { Com compaixão }\end{array}$ & 3.83 & .79 & -.45 & .43 & 3.82 & .80 & -.60 & .88 & 3.84 & .78 & -.33 & .08 \\
\hline 9 & $\begin{array}{l}\text { Emotional } \\
\text { Emocional }\end{array}$ & 4.00 & .80 & -.51 & .06 & 4.04 & .79 & -.53 & .16 & 3.95 & .80 & -.48 & -.07 \\
\hline 10 & $\begin{array}{l}\text { Act as leader } \\
\text { Ajo como um (a) líder }\end{array}$ & 3.32 & 1.02 & -.28 & -.45 & 3.16 & 1.04 & -.49 & .00 & 3.50 & .96 & -.09 & -.62 \\
\hline 11 & $\begin{array}{l}\text { Understanding } \\
\text { Compreensiva }(o)\end{array}$ & 4.06 & .67 & -.64 & 1.49 & 4.12 & .61 & -.78 & 1.55 & 4.00 & .73 & -.31 & .62 \\
\hline 12 & $\begin{array}{l}\text { Independent } \\
\text { Independente }\end{array}$ & 4.07 & .85 & -.89 & .86 & 4.13 & .86 & -.68 & .33 & 4.01 & .84 & -1.08 & 1.41 \\
\hline 13 & $\begin{array}{l}\text { Assertive } \\
\text { Assertiva(o) }\end{array}$ & 3.83 & .77 & -.54 & .63 & 3.84 & .73 & -.60 & .69 & 3.82 & .81 & -.46 & .47 \\
\hline 14 & $\begin{array}{l}\text { Gentle } \\
\text { Gentil } \\
\text { Defends own beliefs }\end{array}$ & 4.15 & .68 & -.63 & .91 & 4.21 & .61 & -.73 & .86 & 4.09 & .75 & -.32 & .21 \\
\hline 15 & $\begin{array}{l}\text { Defendo as minhas } \\
\text { crenças }\end{array}$ & 4.18 & .77 & -.76 & .53 & 4.19 & .76 & -.93 & 1.24 & 4.20 & .78 & -.60 & -.12 \\
\hline 16 & $\begin{array}{l}\text { Energetic } \\
\text { Energética }(o)\end{array}$ & 3.78 & .84 & -.57 & .45 & 3.81 & .84 & -.41 & .17 & 3.76 & .84 & -.71 & .72 \\
\hline 17 & $\begin{array}{l}\text { Competitive } \\
\text { Competitiva(o) }\end{array}$ & 3.41 & 1.01 & -.38 & -.33 & 3.20 & .10 & -.48 & -.12 & 3.66 & .94 & -.26 & -.45 \\
\hline 18 & $\begin{array}{l}\text { Affectionate } \\
\text { Afetuosa }(o)\end{array}$ & 4.08 & .76 & -.76 & .92 & 4.12 & .74 & -.63 & .51 & 4.03 & .77 & -.87 & 1.37 \\
\hline 19 & $\begin{array}{l}\text { Athletic } \\
\text { Atlética }(o)\end{array}$ & 2.78 & 1.12 & .14 & -.69 & 2.56 & 1.11 & -.08 & -.55 & 3.03 & 1.07 & .38 & -.55 \\
\hline 20 & $\begin{array}{l}\text { Dominant } \\
\text { Dominante }\end{array}$ & 3.06 & 1.07 & -.12 & -.44 & 2.95 & 1.09 & -.19 & -.40 & 3.18 & 1.04 & -.05 & -.44 \\
\hline
\end{tabular}




\section{AGENCY AND EXPRESSIVENESS IN MIDDLE AND OLDER AGE}

\section{Construct Validity}

Factor Validity. An Exploratory Factor Analysis was performed and the best fit solution was a 2-factor structure, rotated using the Varimax method. The sampling adequacy was confirmed by the Kaiser-Meyer-Olkin test $(\mathrm{KMO}=.89)$ and the total variance explained by this structure was $41.38 \%$.

All items communalities were above .30 and their factorial weights above .43 , with one exception: item 15 loaded onto both factors and had a factorial weight below 40 in both factors. Nevertheless, it was decided to keep the item so it could be further evaluated in the CFA. Table 3 displays the factorial weights for each item for the total sample and for each gender.

Table 3.

Factor loadings

\begin{tabular}{|c|c|c|c|c|c|c|}
\hline \multirow{2}{*}{ Item } & \multicolumn{2}{|c|}{$\begin{array}{c}\text { Total Sample } \\
\alpha=.86 \\
\end{array}$} & \multicolumn{2}{|c|}{$\begin{array}{l}\text { Women } \\
\alpha=.84 \\
\end{array}$} & \multicolumn{2}{|c|}{$\begin{array}{c}\text { Men } \\
\alpha=.88\end{array}$} \\
\hline & $\begin{array}{c}\text { Expressivenes } \\
\mathrm{s} \\
\alpha=.84 \\
\end{array}$ & $\begin{array}{l}\text { Agency } \\
\alpha=.81\end{array}$ & $\begin{array}{c}\text { Expressiveness } \\
\alpha=.83\end{array}$ & $\begin{array}{l}\text { Agency } \\
\alpha=.79\end{array}$ & $\begin{array}{c}\text { Expressiveness } \\
\quad \alpha=.84\end{array}$ & $\begin{array}{l}\text { Agency } \\
\alpha=.81\end{array}$ \\
\hline 14 & .72 & .05 & .70 & .10 & .73 & .02 \\
\hline 2 & .71 & .02 & .71 & .03 & .71 & .04 \\
\hline 4 & .69 & .14 & .71 & .16 & .66 & .14 \\
\hline 18 & .68 & .19 & .64 & .26 & .71 & .12 \\
\hline 8 & .67 & .20 & .73 & .17 & .64 & .22 \\
\hline 11 & .66 & .12 & .60 & .24 & .68 & .04 \\
\hline 9 & .58 & .16 & .49 & .30 & .62 & .08 \\
\hline 1 & .55 & .14 & .50 & .28 & .58 & .06 \\
\hline 5 & .54 & -.04 & .58 & .01 & .55 & -.12 \\
\hline 6 & .43 & .24 & .44 & .21 & .43 & .25 \\
\hline 10 & -.03 & .78 & .01 & .78 & -.02 & .78 \\
\hline 20 & -.06 & .77 & .00 & .78 & -.09 & .78 \\
\hline 17 & .01 & .74 & .18 & .70 & -.07 & .74 \\
\hline 3 & .29 & .60 & .38 & .54 & .02 & .45 \\
\hline 7 & .21 & .58 & .30 & .50 & .17 & .59 \\
\hline 13 & .35 & .51 & .38 & .51 & .31 & .54 \\
\hline 19 & .03 & .50 & .09 & .52 & .05 & .45 \\
\hline 12 & .28 & .50 & .34 & .46 & .21 & .55 \\
\hline 16 & .20 & .47 & .14 & .43 & .24 & .52 \\
\hline 15 & .39 & .37 & .36 & .38 & .41 & .35 \\
\hline
\end{tabular}

Confirmatory Factor Analysis. A CFA was performed to confirm the factorial structure obtained in the previous analysis. The model adjustment was acceptable, except for items 6 and 19, which had both factorial weights and multiple squared correlations below the recommended values (item 6: $\lambda=.43 ; \mathrm{R}^{2}=.23$; item $\left.19: \lambda=.41 ; \mathrm{R}^{2}=.24\right)$, justifying their exclusion. However, item 15 presented better values than in the EFA $\left(\lambda=.44 ; R^{2}=.27\right)$, which justified its permanence. Although the removal of items 6 and 19 did not significantly improve model-fit, it was decided to eliminate them due to their low factorial weight.

Multi-Group Confirmatory Factor Analysis. A MG-CFA was performed to test the factorial structure invariance in men and women. The baseline model (Model 2a) without constraints, revealed acceptable fit indices for each subsample. The second model (Model 2b), which constrains the factor loadings, revealed invariance between groups $\left(\Delta \chi^{2}=11.466, d f=16, p=.780\right)$, since the $\Delta \chi^{2}$ was lower than the standardized $\Delta \chi^{2}$ for a significance level of .005 (confidence level of .95). 
The third model (Model 2c), which constraints the structural covariances, also presented invariance between groups $\left(\Delta \chi^{2}=26.342, d f=19, p=.121\right)$. Conversely, Model $2 \mathrm{~d}$, which constraints the measurement residuals, did not show invariance between groups $\left(\Delta \chi^{2}=104.079, d f=42, p<.001\right)$, since the $\Delta \chi^{2}$ was higher than the standardized $\Delta \chi^{2}$ for a significance level of .005 (confidence level of .95) (Table 4).

\section{Table 4.}

Factorial Weights

\begin{tabular}{cllccc}
\hline & & $\begin{array}{c}\text { Initial CFA } \\
\text { with 20 items }\end{array}$ & $\begin{array}{c}\text { Initial CFA } \\
\text { with 18 items }\end{array}$ & \multicolumn{2}{c}{$\begin{array}{c}\text { Final } \\
\text { MG-CFA }\end{array}$} \\
\cline { 3 - 7 } Item & Factor & .54 & .52 & .54 & .50 \\
\hline 1 & Expressiveness & .66 & .63 & .65 & .61 \\
2 & Expressiveness & .65 & .65 & .62 & .68 \\
4 & Expressiveness & .45 & .45 & .46 & .48 \\
5 & Expressiveness & .43 & - & - & - \\
6 & Expressiveness & .43 & .65 & .62 & .68 \\
8 & Expressiveness & .67 & .53 & .53 & .53 \\
9 & Expressiveness & .57 & .63 & .65 & .62 \\
11 & Expressiveness & .62 & .68 & .70 & .65 \\
14 & Expressiveness & .66 & .68 & .68 & .68 \\
18 & Expressiveness & .67 & .68 & .68 & .68 \\
3 & Agency & .63 & .56 & .54 & .56 \\
7 & Agency & .56 & .61 & .57 & .54 \\
10 & Agency & .70 & .56 & .60 & .56 \\
12 & Agency & .52 & .60 & .61 & .61 \\
13 & Agency & .55 & .49 & .50 & .50 \\
15 & Agency & .44 & .45 & .54 & .36 \\
16 & Agency & .44 & .56 & .46 & .58 \\
17 & Agency & .64 & - & - & - \\
19 & Agency & .41 & .53 & .47 & .50 \\
20 & Agency & .66 & & & \\
\hline
\end{tabular}

Results evidenced the invariance of the factor loadings and structural covariances and noninvariance of the measurement residuals for the Bem Sex-Role Inventory, when comparing men and women. Accordingly, the factor structure of BSRI can be used in samples of both genders (Table 5). 


\section{AGENCY AND EXPRESSIVENESS IN MIDDLE AND OLDER AGE}

Table 5.

Goodness of fit statistics for the measurement models and factorial invariance

\begin{tabular}{lcccccc}
\hline \multicolumn{1}{c}{ Description } & $\chi^{\mathbf{2}}$ & $\boldsymbol{d f}$ & CFI & GFI & RMSEA & $\begin{array}{c}\text { RMSEA CI } \\
{[\mathbf{9 0 \%} \%}\end{array}$ \\
\hline $\begin{array}{l}\text { Model 1 - Measurement } \\
\text { model }\end{array}$ & & & & & & \\
$\quad$ 1a. 20 items & 614.298 & 165 & .877 & .908 & .066 & $.060, .071$ \\
$\quad$ 1b. 18 items & 468.748 & 130 & .899 & .921 & .064 & $.058, .071$ \\
$\begin{array}{l}\text { Model 2 - Multiple-group } \\
\text { analysis }\end{array}$ & & & & & & \\
$\quad$ 2a. Unconstrained & 628.948 & 258 & .892 & .900 & .048 & $.043, .053$ \\
2b. MW & 640.415 & 274 & .894 & .899 & .046 & $.042, .042$ \\
2c. MW + SC & 655.290 & 277 & .890 & .897 & .047 & $.042, .051$ \\
2d. MW + SC + MR & 733.027 & 300 & .874 & .884 & .048 & $.044, .052$
\end{tabular}

Note. ${ }^{*} * p<.001 . \mathrm{CFI}=$ Comparative Fit Index; NFI = Non-normed fit index; RMSEA = Root Mean

Square Error of Approximation; $\mathrm{CI}=$ Confidence Interval 90\%; FL = Measurement Weights; $\mathrm{SC}=$

Structural Covariances; MR = Measurement Residuals.

Convergent and Discriminant Validities. Both factors displayed high values $(<.70)$ of Composite Reliability (CR), indicating a good internal consistency. Factors presented values of Average Variance Expected (AVE) between .30 and .37, suggesting weak convergent validity. To assess discriminant validity, AVE values must be higher than the squared correlation between factors. The discriminant validity for the total sample $\left(\mathrm{R}^{2}\right.$ Total Sample $\left.=.54^{2}=.29\right)$ was confirmed given that the values of the AVE were between .31 and .37. In the assessment by gender, discriminant validity was confirmed for women $\left(\mathrm{R}^{2}\right.$ Women $\left.=.46^{2}=.21\right)$ given that the values of AVE for this group were between .31 and .37. However, discriminant validity was not assured for men $\left(\mathrm{R}^{2}\right.$ Men $\left.=.72^{2}=.52\right)$, with AVE values between .30 and .37 . The AVE and CR values are shown in Table 6.

Table 6.

Average Variance Extracted and Composite Reliability

\begin{tabular}{lcccccc}
\hline Factor & \multicolumn{2}{c}{ Total Sample } & \multicolumn{2}{c}{ Women } & \multicolumn{2}{c}{ Men } \\
\hline & AVE & CR & AVE & CR & AVE & CR \\
\cline { 2 - 7 } Total Scale & .34 & .90 & .34 & .90 & .34 & .90 \\
Expressiveness & .37 & .84 & .37 & .84 & .37 & .84 \\
Agency & .31 & .80 & .31 & .80 & .30 & .79 \\
\hline
\end{tabular}

\section{DISCUSSION}

The goal of this study was to evaluate the psychometric properties of the Bem Sex-Role Inventory (BSRI; Bem, 1974, 1981) in a middle and older aged Portuguese sample. We decided to focus exclusively on two essential gender dimensions: "Agency/Instrumentality" and "Expressiveness/Communication"; which derive from the perception of femininity as expressive and masculinity as instrumental.

The results provided evidence of sensitivity and reliability of the BSRI. Further, the results from the exploratory factorial analysis confirmed the adequacy of the two-factor structure, and the 


\section{P.A. Costa, P. Mangia, C.C.Tomás, F. Pimenta, J.Maroco, \& I. Leal}

confirmatory factor analysis evidenced a good fit of the two-factor model after the removal of two items: item 6 ("sympathetic") and 19 ("athletic"). Although the items were removed to achieve a good model fit, further factorial studies are recommended to corroborate this decision. The final first-order 18 items factorial structure presented a two-dimension model Agency/Instrumentality and Expressiveness, with a very good fit. Lastly, the invariance of the BSRI between women and men was also examined and model invariance for both groups was confirmed, further evidencing the reliability and adequacy of the BSRI for both genders.

In order to conduct a psychometric comparison, the studies of Colley, Mulhern, Maltby and Wood (2009) and of Formiga and Camino (2001) were examined due to their similar approach of BSRI that focused solely on the dimensions of Agency/Instrumentality and Expressiveness, using short versions of 20 and 18 items, respectively. The study of Colley et al. (2009) was performed with a student sample from the United Kingdom and failed to confirm the factorial structure of the Instrumentality/Agency and Expressiveness dimensions of the BSRI. The two-factor structure showed a very poor fit, as did a three-factor model tested. By way of contrast, we obtained a twofactor structure with a good fit, and invariance was confirmed for men and women. One possible reason for these disparities could be related to the items we selected for our version through the process of face validity, which resulted in slight differences in some of the items used when compared to the UK study. Additionally, the age differences between the samples may also account for the different results; while the U.K. and the Brazilian study sampled young participants, our sample was composed of middle and older aged participants. Formiga and Camino's (2001) study applied the BSRI version of 18 items to a young Brazilian sample. Factorial validity was performed only at an exploratory level, but the results were in the same direction of the present study, i.e., both men and women associated levels of expressive traits with traditional femininity and levels of instrumental traits with traditional masculinity.

There are very few validation studies of BSRI in western older adult populations (Vafaei et al, 2014), but two studies were found to had both cultural and age-related similarities: one was performed in Spain by Vafaei et al. (2014) and the other in Brazil by Carver et al. (2013). Both studies used a short form of BSRI, comprising 12 items, in a sample aged above 65 years; their factorial analyses also confirmed a two-factor structure composed by Instrumentality/Agency and Expressiveness/Communication. However, despite the Brazilian study's (Carver et al., 2013) confirmation of the factorial structure, the scale's internal consistency was weak, possibly due to the reduced number of items. Differently, the Spanish study (Vafaei et al, 2014) had a good reliability with the same number of items, suggesting that a new equally shorter version of the BSRI could also be tested in Portugal.

This study has some limitations that must be acknowledged. A convenience sample of middle and older aged adults, drawn from a larger study on perceived health, was used. As such, generalization to the population cannot be ascertained. A further limitation regards the structure of the scale, specifically the removal of the two items from the scale, which requires further exploration. Considering recent studies that have used an even shorter version (12 items), further studies should address the reliability of a shorter BSRI. As for the assessment of the BSRI validity, the convergent validity of both factors was weak, as was the discriminant validity among men.

In summary, this was the first study to adapt and validate the short form of the Bem Sex-Role Inventory focused on Agency/Instrumentality and Expressiveness/Communication in Portugal. Although further validation studies are advisable, the current study provided evidence of high internal reliability and of face and construct validities of the 18-item version of BSRI for a middle 


\section{AGENCY AND EXPRESSIVENESS IN MIDDLE AND OLDER AGE}

and older aged Portuguese sample, which was confirmed through a Factorial Analysis, namely Confirmatory Factor Analysis and Multi-Group Factor Analysis. Future studies should focus on the examination of external validation, convergent and divergent validities, as well as on younger Portuguese samples.

\section{REFERENCES}

Athenstaedt, U. (2003). On the content and structure of the gender role self-concept: Including gender-stereotypical behaviors in addition to traits. Psychology of Women Quarterly, 27, 309-318. doi: 10.1111/1471-6402.00111

Auster, C. J., \& Ohm, S. C. (2000). Masculinity and femininity in contemporary American society: A reevaluation using the Bem Sex-Role Inventory. Sex roles, 43, 499-528. doi: 10.1023/A:1007119516728

Beaton, D. E., Bombardier, C., Guillemin, F., \& Ferraz, M. B. (2000). Guidelines for the process of cross-cultural adaptation of self-report measures. Spine, 25, 3186-3191. doi: 10.1097/00007632200012150-00014

Bem, S. L. (1974). The measurement of psychological androgyny. Journal of Consulting and Clinical Psychology, 42, 155-162. doi: 10.1037/h0036215

Bem, S. L. (1977). On the utility of alternative procedures for assessing psychological androgyny. Journal of Consulting and Clinical Psychology, 45, 196-205. doi: 10.1037//0022006X.45.2.196

Bem, S. L. (1981a). Gender schema theory: A cognitive account of sex typing. Psychological review, 88, 354-364. doi: 10.1037/0033-295X.88.4.354

Bem, S. L. (1981b). A manual for the Bem Sex Role Inventory. Palo Alto, CA: Consulting Psychologist Press.

Bussey, K., \& Bandura, A. (1984). Influence of gender constancy and social power on sex-linked modeling. Journal of Personality and Social Psychology, 47, 1292. doi: 10.1037//00223514.47.6.1292

Carver, L. F., Vafaei, A., Guerra, R., Freire, A., Phillips, S. P. (2013). Gender differences: Examination of the 12-item Bem Sex Role Inventory (BSRI-12) in an older Brazilian population. PLOS ONE, 8(10). doi: 10.1371/journal.pone.0076356

Cheng, C. (2005). Processes underlying gender-role flexibility: Do androgynous individuals know more or know how to cope? Journal of Personality, 73, 645-674. doi: 10.1111/j.14676494.2005.00324.x

Colley, A., Mulhern, G., Maltby, J., \& Wood, A. M. (2009). The short form BSRI: Instrumentality, expressiveness and gender associations among a United Kingdom sample. Personality and Individual Differences, 46, 384-387. doi: 10.1016/j.paid.2008.11.005

Diekman, A. B., \& Eagly, A. H. (2000). Stereotypes as dynamic constructs: Women and men of the past, present, and future. Personality and Social Psychology Bulletin, 26, 1171-1188. doi: $10.1177 / 0146167200262001$

Eagly, A. H., Wood, W., \& Diekman, A. B. (2000). Social role theory of sex differences and similarities: A current appraisal. In T. Eckes, \& H. M. Trautner (Eds.), The developmental social psychology of gender (pp. 123-174). New Jersey: Erlbaum.

Gibbons, J. L., Hamby, B. A., \& Dennis, W. D. (1997). Researching gender-role ideologies internationally and cross-culturally. Psychology of Women Quarterly,21, 151-170. doi: 10.1111/j.1471-6402.1997.tb00106.x 
Guillemin, F., Bombardier, C., \& Beaton, D. (1993). Cross-cultural adaptation of health-related quality of life measures: Literature review and proposed outlines. Journal of Clinical Epidemiology, 46, 1417-1432. doi: 10.1016/0895-4356(93)90142-N

Hoffman, R. M., \& Borders, L. D. (2001). Twenty-five years after the Bem Sex-Role Inventory: A reassessment and new issues regarding classification variability. Measurement and Evaluation in Counseling and Development, 34, 39. ISSN: ISSN-0748-1756

Holt, C. L., \& Ellis, J. B. (1998). Assessing the current validity of the Bem Sex-Role Inventory. Sex Roles, 39, 929-941. doi: 10.1023/A:1018836923919

Jackson, L. A., Hodge, C. N., \& Ingram, J. M. (1994). Gender and self-concept: A reexamination of stereotypic differences and the role of gender attitudes. Sex Roles, 30, 615-630. doi: 10.1007/BF01544666

Kachel, S., Steffens, M. C., \& Niedlich, C. (2016). Traditional masculinity and femininity: Validation of a new scale assessing gender roles. Frontiers in Psychology, 7, 956. doi: 10.3389/fpsyg.2016.00956

Konrad, A. M., \& Harris, C. (2002). Desirability of the Bem Sex-Role Inventory items for women and men: A comparison between African Americans and European Americans. Sex Roles, 47, 259-271. doi: 10.1023/A:1021386727269

Lueptow, L. B., Garovich-Szabo, L., \& Lueptow, M. B. (2001). Social change and the persistence of sex typing: 1974-1997. Social Forces, 80, 1-36. doi: 10.1353/sof.2001.0077

Maccoby, E. E. (2000). Perspectives on gender development. International Journal of Behavioral Development, 24, 398-406. doi: 10.1080/016502500750037946

Nosek, B.A., Banaji, M.R., \& Greenwald, A.G. (2002). Math = male, me = female, therefore math $\neq$ me. Journal of Personality and Social Psychology, 83, 44-59. doi: 10.1037/00223514.83.1.44

Parsons, T., \& Bales, R. F. (1955). Family, Socialization and Interaction Processes. New York: Free Press of Glencoe.

Sczesny, S., Bosak, J., Neff, D., \& Schyns, B. (2004). Gender stereotypes and the attribution of leadership traits: A cross-cultural comparison. Sex roles, 51, 631-645. doi: 10.1007/s11199-0040715-0

Smiler A. P., \& Epstein M. (2010). Measuring gender: Options and issues. In: J. Chrisler \& D. McCreary (Eds.), Handbook of Gender Research in Psychology (pp. 133-157). New York: Springer.

Smiler, A. P., \& Gelman, S. A. (2008). Determinants of gender essentialism in college students. Sex Roles, 58, 864-874. doi: 10.1007/s11199-008-9402-x

Smiler, A. P., Kay, G., \& Harris, B. (2009). Tightening and loosening masculinity's (k)nots: Masculinity in the Hearst press during the interwar period. The Journal of Men's Studies, 16, 266279. doi: $10.3149 /$ jms.1603.266

Smiler, A. P., \& Kubotera, N. (2010). Instrumental or expressive? Heterosexual men's expectations of women in two contexts. Men and Masculinities, 12, 565-574. doi: 10.1177/1097184X09337112

Steffens, M. C., Jelenec, P., \& Noack, P. (2010). On the leaky math pipeline: Comparing implicit math-gender stereotypes and math withdrawal in female and male children and adolescents. Journal of Educational Psychology, 102, 947-963. doi: 10.1037/a0019920

Steffens, M. C., \& Viladot, M. A. (2015). Gender at work: A social psychological perspective. New York: Peter Lang. 


\section{AGENCY AND EXPRESSIVENESS IN MIDDLE AND OLDER AGE}

Twenge, J. M. (1997). Changes in masculine and feminine traits over time: A meta-analysis. Sex Roles, 36, 305-325. doi: 10.1007/BF02766650

Weiten, W. (1997). Psychology: Themes and variations, briefer version (3rd ed.). Pacific Grove, CA: Brooks/Cole Publishing Company.

Vafaei, A., Alvarado, B., Tomás, C., Muro, C., Martinez, B., \& Zunzunegui, M. V. (2014). The validity of the 12-item Bem Sex Role Inventory in older Spanish population: An examination of the androgyny model. Archives of Gerontology and Geriatrics, 59, 257-263. doi: 10.1016/j.archger.2014.05.012

Wilde, A., \& Diekman, A. B. (2005). Cross-cultural similarities and differences in dynamic stereotypes: A comparison between Germany and the United States. Psychology of Women Quarterly, 29, 188-196. doi: 10.1111/j.1471-6402.2005.00181.x 